\title{
How do Market Orientation and Learning Orientation Impact on Born Global Firm Performance? The Synergistic Effect
}

\author{
Herath, H.M.T.S. \\ Department of Commerce and Financial Management, University of Kelaniya, Sri Lanka. \\ tish@kln.ac.lk
}

\begin{abstract}
The purpose of this study was to examine how Market Orientation (MO) and Learning Orientation (LO) influence the international performance of born global firms and to enrich the existing literature with empirical evidence from an emerging country context, Sri Lanka, yet an inclusive research area. The findings of the study were analyzed using 225 ICT export entrepreneurs in Sri Lanka, and the hypotheses were tested using structural equation modeling. The findings reveal that MO and LO significantly influence the international performance of born global firms, and further, it found that LO mediates the MO-Performance relationship, confirming the synergistic effect. The paper then discusses the managerial implications of the findings of the study.
\end{abstract}

Keywords: Born global firms, International performance, Learning Orientation, Market Orientation

Copyright: (C) 2021 Herath, H.M.T.S. This is an open access article distributed under the Creative Commons Attribution License, which permits unrestricted use, distribution, and reproduction in any medium, provided the original work is properly cited.

Correspondence: tish@kln.ac.lk

ORCID of authors: Herath, H.M.T.S. - (iD https://orcid.org/0000-0003-4538-838X

DOI: http://doi.org/10.4038/kjm.v10i2.7697 


\section{Introduction}

Born global firms - "entrepreneurial startups that, from or near their founding, seek to derive a substantial proportion of their revenue from the sale of products in international markets" (Knight \& Cavusgil, 2004, p. 124) - still a novel and emerging phenomenon and a line of research in the domain of international entrepreneurship. Unlike other internationalized firms, born global firms exhibit unique characteristics in common, and some of those prominent features are small in scale, entrepreneurial in nature, follow proactive internationalization strategy and use hybrid structures. According to the conventional internationalization theories, the internationalization of firms is a gradual and incremental process. But going against the conventional internationalization theories, born global firms exhibit greater and continuous success in the global market than other internalized firms - from large MNEs to SMEs. Despite their greater resource constraints - mainly with tangible resources, born global firms are rich with intangible resources and capabilities which are unique and distinctive that create their competitive advantage in the global market and lead their superior performance (Cavusgil \& Knight, 2015; Jantunen et al., 2008; Knight \& Liesch, 2016; Rialp et al., 2005).

Various theoretical perspectives and empirical findings on born global firms have highlighted the importance and the role of firm-level resources, capabilities and competencies as drivers, mediators, and moderators that influence internationalization, superior performance and long-term survival of born global firms (Knight \& Liesch, 2016; Moen \& Servais, 2002; Oviatt \& McDougall, 2005; Rialp \& Rialp, 2007). Among those resources, capabilities and competencies, specific orientations - mainly entrepreneurial, business strategies and competencies play a dominant role in the superior performance of born global firms (Knight \& Liesch, 2016).
Key orientations that emphasized in previous scholarly works include entrepreneurial orientations (Covin \& Miller, 2014; Covin \& Slevin, 1991; Jantunen et al., 2008; Knight \& Cavusgil, 2004; Rauch et al., 2009; F. Wang et al., 2018; Wiklund \& Shepherd, 2005), market orientations (Baker \& Sinkula, 1999; Charles et al., 2012; Deng \& Dart, 1994; Knight \& Cavusgil, 2004; Kropp et al., 2006; Narver \& Slater, 1990; Rodriguez Cano et al., 2004), learning orientations (Baker \& Sinkula, 1999; Calantone et al., 2002; Calisir et al., 2013; Gabrielsson et al., 2014; Jantunen et al., 2008; Kropp et al., 2006; C. L. Wang, 2008), network orientations (Chun et al., 2014; Dimitratos et al., 2012; Falahat et al., 2018; Gabrielsson et al., 2014), growth orientations (Nummela et al., 2005; Sundqvist \& Kuivalainen, 2009), technology orientations (Knight \& Liesch, 2016; Masa'deh et al., 2018), and business strategies include technological competency, unique product development, quality focus, customer focus (Knight \& Cavusgil, 2004; Knight, et al., 2004). These specific orientations and capabilities are firm-level intangible resources and are unique, rare, and hard to copy, and thus, born global firms, even in the same industry, enjoy a greater sustainable competitive advantage that accelerates their superior international performance (Knight \& Liesch, 2016; Mac \& Evangelista, 2016).

A significant number of scholarly works has been conducting on born global firms for more than two decades, but most of them are from well-developed and advanced economies, except very few from emerging economies (Cavusgil \& Knight, 2015; Falahat et al., 2018; Knight \& Liesch, 2016). Scholarly works on born global firms are still evolving in the context of emerging economies (Akoorie \& Sinha, 2012; Falahat et al., 2018; Felzensztein et al., 2015; Peiris et al., 2012). Moreover, a great deal of research has been emphasized the positive influence of market orientation and learning orientation on the performance of born global firms, but many of those studies are 
theoretically proposed scholarly works, not empirically tested exclusively (Baker \& Sinkula, 1999; Kropp et al., 2006; Mac \& Evangelista, 2016), particularly in emerging country contexts. In addition, the interrelationship between market and learning orientations are least understood (Sinkula et al., 1997). Similarly, even if many recent scholarly works have proposed indirect effect of learning orientation on market orientation - performance relationship of born global firms, empirical investigations are not significantly visible in the international entrepreneurship literature (Baker \& Sinkula, 1999; Keupp \& Gassmann, 2009; Knight \& Liesch, 2016; Mac \& Evangelista, 2016). As Peiris, et al., (2012); Felzensztein, et al., (2015) highlighted, there is a dearth of research on born global firms from the south-east Asian context and to best of my understanding, no studies found in the Sri Lankan context. Thus, despite much previous research on market orientation, learning orientation, and international performance of born global firms, some questions are still unanswered. One such appealing question is how market and learning orientations together influence the achievement of superior international performance of born global firms in a more dynamic and complex global environment. Therefore, in addressing these gaps in the extant literature, this study attempts to enrich the exiting literature on born global firm performance with empirical evidence from an emerging country context, Sri Lanka with special reference to Information and Communication Technology (ICT) export entrepreneurs in which it facilitates to revalidate the existing theories and models in a completely new context. In particular, this study attempts to extend the existing knowledge on born global performance from emerging markets by examining the direct effect of market and learning orientation on the international performance of born global firms and the indirect effect of learning orientation on the MO-Performance relationship.
Sri Lanka, in particular ICT Industry, was chosen as the study context due to several important factors. First, Sri Lanka is one of the booming emerging economies in the south-east Asian region that is completely different from well-developed and advanced economies in terms of economic, social, political, and business stability, environment, and characteristics. Second, Sri Lanka has increasingly been recognized as one of the fast-growing and emerging outsourcing destinations for ICT industry in the Asian region. Moreover, Sri Lanka ranks among the top five emerging countries with a sound business climate and is the 4th largest export earners in the ICT industry with more than 95 percent value addition (Export development Board of Sri Lanka, 2011). Third, ICT export entrepreneurs in Sri Lanka exhibit exactly the born global characteristics (Herath \& Karunaratne, 2015). Thus, ICT industry in Sri Lanka has been recognized as a promising services export sector, having a greater potential growth and a greater possibility of expanding the market share. Hence, both Central Bank of Sri Lanka and Export Development Board (EDB) have identified the ICT sector as one of seven key sectors, contributing more than 3.3 percent to the total export. But those ICT export entrepreneurs in Sri Lanka are not performing well as expected and far below the expected growth rates, and the industry growth is gradually declining since 2011. While some ICT export entrepreneurs achieve superior performance in the global market, some fail. Various obstacles, difficulties and other resource constraints encountered in the external environment may not be the sole reason for their failure, and these are, however, shortterm and temporal. Under this vein, what actually drives ICT born global firms to their superior performance in the international market was the puzzle and the motive for this study. The research problem of the study was developed under this scenario, and in conceptualizing, the study hypothesized that a firm's market orientation and learning orientation are the most decisive factors influencing the superior international performance of born global firms. 
Based on the resource-based view, this study aims to examine the influence of two main specific orientations - market orientation and learning orientation - on the international performance of born global firms in the context of Sri Lanka with special reference to ICT industry. The potential contribution of this study is significant. First, this study advances the existing knowledge on market orientation, learning orientation and born global performance from the emerging country context that fills a greater room in the international entrepreneurship field. Second, this study brings empirical evidence from an emerging economy to provide a new insight into analyzing the relationship among market orientation, learning orientation and international performance of born global firms - considering both direct and indirect impacts. Third, the findings of this study help export entrepreneurs on how they could enhance their competitive advantage and international performance in the long run through these specific orientations.

The next section will discuss the theoretical background of this study - the resourcebased view and subsequently the conceptualization and hypotheses development, research methods, data analysis and results, discussion, managerial implications, and finally, the study limitations with future research directions.

\section{Theoretical Perspective - The Resource-based View}

The main research question of this study attempted to answer is how market orientation and learning orientation together influence to enhance the superior international performance of born global firms. The resource-based view provides the necessary theoretical support to identify the interrelationship between market and learning orientations and to conceptualize the impact of market and learning orientation on the international performance of born global firms. Resource-based view arose as a main challenger to the conventional stages theories of internationalization and still remains as one of the prominent and widely used theoretical perspectives in understanding the international entrepreneurship phenomenon (Peiris et al., 2012). The resource-based view is connected with the competitive advantage of international firms rather than export firms. Basically, this theoretical framework emphasizes the importance of firm-specific resources and capabilities in generating and maintaining sustainable competitive advantage, which allows a firm to earn above normal economic profits (Rialp \& Rialp, 2007). Thus, resource-based view stresses the usefulness of analyzing the firm from the side of resources rather than the product side (Wernerfelt, 1984), which is the main focus of the traditional internationalization theories of the firm. The resource-based view suggests that firms in the same industry perform differently because they differ in their resources and capabilities and these differences may be long-lasting (Barney, 1991). Thus, the main assumption behind the resource-based view is that resources are heterogeneously distributed among firms in the same industry. Thus, by identifying specific sources of sustained competitive advantage, the resource-based view offers a sound understanding of why some firms can consistently outperform their rivals in the marketplace (Rialp \& Rialp, 2007). Thus, with the theoretical support of the resourcebased view and the available literature, it is justifiable to build the argument that strong market orientation and learning orientation of born global firms leads them their superior performance and long-term survival in the international market.

\section{Conceptualization and Hypotheses Development}

\section{International Performance of Born Global Firms}

International performance of born global firms is the recent focus in relating to born global studies. Recent studies greatly concern the decisive factors in the performance of 
these firms. Based on various theoretical perspectives, extant literature provides many different approaches to examine firm performance and has used many different factors at different levels to determine firm performance. According to Covin \& Slevin (1991), all these antecedents can be categorized into three broader categories of: internal variables, external variables and strategic variables. Internal variables of performance have received a great deal of attention in the available literature. Internal variables refer to the internal environment of a firm. According to Covin \& Slevin (1991), these internal variables can be broadly categorized into four as top management values and philosophies, organizational resources and competencies, organizational culture, and organizational structure. Strategic variables represent strategic competencies and refer to the managerial skills needed for managers in performing key strategic functions of a firm (Knight, 2001). Strategic variables include a firm's mission strategies and its business practices and tactics. The external variables refer to the external environment of a firm. Thus, external variables include all factors external to the firm and are affected by several macro variables such as economic, socio-cultural, political, legal, and technological forces. The conditions and changes of these factors influence the firm's operations and, ultimately, its performance. According to Lumpkin \& Dess (1996), external environment factors can be broadly categorized into four: environmental dynamism, environmental munificence, environmental complexity and industry characteristics.

However, the available literature on the drivers of born global international performance is limited. Many of these drivers are entrepreneurial. According to the metaanalysis of over 179 articles done by Keupp \& Gassmann (2009), they categorized all antecedents of born global performance into four broader categories; personal level, firmlevel, industry level, and country level.
Personal level antecedents include the variables of managers' socio-cognitive properties and managers' demographic factors. Mostly studied firm-level antecedents include organizational culture and orientations, business strategies, organizational learning, R\&D intensity, market share and size, resources and capabilities, firm ownership, advertising intensity, and international experience. Variables such as inter-firm networks, foreign and domestic industry structure, government policy, and industry competition represent the industry level antecedents. Finally, country-level antecedents include the factors of cultural distance and host country issues. However, as Keupp \& Gassmann (2009) found in their study, the mostly studied antecedent of performance of born global firms are socio-cognitive factors at the individual level and patterns and degrees of internationalization at the firm level.

In summary, internal variables tend to record a direct relationship with the international performance of born global firms in many research studies conducted. While some studies found a direct relationship with the international performance of born global firms with regard to external variables and strategic variables, others reported an indirect relationship in the form of either moderators or mediators.

\section{Market Orientation}

Market orientation has long been acknowledging as a significant driver of performance, leading a business for its longterm success (Cano et al., 2004). A firm with a strong market orientation has a higher likelihood of creating a sustainable competitive advantage, and thus, market orientation has synergistic effects on performance (Baker \& Sinkula, 1999; Charles et al., 2012; Deng \& Dart, 1994; Mac \& Evangelista, 2016). Any business firm, aiming at consistent abnormal business performances, should focus on sustainable 
competitive advantage that can only gain by creating sustainable superior value for its customers, meeting customer satisfaction beyond their expectations (Narver \& Slater, 1990). As Narver \& Slater (1990), market orientation is a firm-level phenomenon rather than a firm-level resource, embedded in organizational culture. Thus, it enables firms to be alert on customer needs, expectations, changes, competitor actions and reactions and business and environmental changes. Such an alert on various stakeholders is a must for firms operating in the international market, especially the resource-constrained small firms - the born global firms, mainly because they do not have close, continuous, and physical contacts with their customers (Baker \& Sinkula, 1999; Mac \& Evangelista, 2016). Thus, as these scholars recommend, born global firms need to develop a strong market orientation within their organizational culture to find their competitive advantage for the long-term survival.

The existing literature provides several different definitions and conceptualizations of market orientation. But all have a common focus on customers, competitors, information acquisition, information dissemination, and responsiveness (Baker \& Sinkula, 1999). These definitions suggest that market orientation is not just a discrete phenomenon but is continuous. Narver \& Slater (1990) define market orientation as "the organization-culture that most effectively and efficiently creates the necessary behaviour for the creation of superior value for buyers and thus continuous superior performance for the business" (p. 21). Market orientation is not just acquiring information from their customers and other channels regarding their needs and preferences, but more than that (Kohli \& Jaworski, 1990). Thus, market-oriented firms acquire, disseminate and respond to information through customers, competitors and various other channels to offer a superior value for their customers than their competitors. Following Narver and Slater (1990), international market orientation could be operationalized in terms of organizational culture, and it comprises of three elements: international customer orientation, international competitor orientation, and inter-functional coordination. While customer Orientation and competitor orientation refer to all the activities relating to obtaining information about the firm's customers and competitors in the target market and disseminating them throughout the firm, inter-functional coordination engages with all the efforts of coordinating firm's resources to create a superior value for the customers (Narver \& Slater, 1990). Narver \& Slater's approach to market orientation provides relatively more variance in explaining business performance. Because MKTOR scale, developed by Narver \& Slater (1990), captures the different aspects of market orientation which has a direct link to performance than other conceptualizations of market orientation.

Even though market orientation has been comprehensively conceptualized, a very few studies have been conducted in the international entrepreneurship domain (Dimitratos \& Plakoyiannaki, 2003). Despite few studies finding a negative or no relationship, most studies have found a significant and positive relationship between market orientation and the international performance (Abbu \& Gopalakrishna, 2019; Baker \& Sinkula, 1999; Hartsfield et al., 2008; Jaworski \& Kohli, 1993; Kropp et al., 2006; Mac \& Evangelista, 2016; Narver \& Slater, 1990; Rodriguez Cano et al., 2004; Slater \& Narver, 1995). Accordingly, this study hypothesizes,

$\mathrm{H} 1:$ Market Orientation (MO) is positively related to the international performance of born global firms.

\section{Learning Orientation (LO)}

International learning orientation refers to the proclivity of the firm to acquire intelligence on foreign markets and make use of it to its maximum (Gabrielsson et al., 2014). Baker 
\& Sinkula (1999) define learning orientation as an organizational characteristic that affects higher-order learning (i.e., a firm's propensity to value generative and doubleloop learning). According to Jantunen et al. (2008), learning orientation is not just acquiring knowledge from customers and competitors. Thus, it refers to acquiring, creating and transferring knowledge, and challenging existing values and norms to reproduce new knowledge and insights for new value acquisition (Wang, 2008). Like market orientation, learning orientation is also a key aspect of organizational culture and is a firm-level resource that enhances the firm's sustained competitive advantage (Long, 2013). Thus, imitating the learning orientation of a firm finds difficult as learning orientation is attached with firm-specific knowledge creation and sharing, which happen internally to the firm. Learning orientation of a firm offers numerous benefits, first; learning orientation of a firm is one of the key components of its strategic renewal, second; organizational learning connects the firm and its environment, third; learning is forward-looking, learning orientation assists firm to keep close relationships with its stakeholders, including customers, suppliers, competitors, employees, and fifth, learning orientation plays a dominant role in opportunity recognition (Kropp et al., 2006). On the other hand, the performance of a firm reflects the effectiveness and efficiency of its learning process. Thus, firm performance and organizational learning depends on one another.

Organizational learning is a higher-order construct (Baker \& Sinkula, 1999). To date still, there is no one agreement upon how to conceptualize learning orientation. The conceptualization of learning orientation is based on two approaches: one focuses on knowledge acquisition and the other on value acquisition (C. L. Wang, 2008). As she further pointed out, these two approaches to learning orientation should not be investigated in isolation, and the combination of both aspects is preferable. Thus, different authors have conceptualized learning orientation from different perspectives. Sinkula, et al. (1997) operationalize learning orientation from three aspects: commitment to learning, shared vision and open mindedness. According to Sinkula et al. (1997), commitment to learning refers to the extent to which a firm places value on learning and promotes a learning culture within the firm. This will eventually create a learning climate. Open-mindedness refers to the extent to which a firm "proactively question long-held routines, assumptions and beliefs and is linked to the notion of unlearning" (Sinkula et al., 1997, p. 309). Further to them, unlearning is central to organizational change, and open-mindedness is an organizational value that facilitates unlearning efforts to transpire. Therefore, firms should always go beyond not just depending on learning from their past successes and failures. These past learning experiences, information embedded in their long-held routines and processes may no longer hold true when the external environment changes (Wang, 2008). Thus, open-minded firms critically evaluate their traditional operational routines and seek new ways of looking at them (Calantone et al., 2002). Third, shared vision refers to deeply shared goals and missions which direct organizational employees to work toward a common goal and give them a sense of destiny (Sinkula et al., 1997). Shared vision influences the direction of the learning process and thus, it is different from other the two aspects of commitment to learning and open-mindedness which influence the intensity of learning (Sinkula et al., 1997). A clear direction for learning leads to increasing the strength of the firm and to enhance quality of learning (Calantone et al., 2002). Thus, "without a shared vision, individuals are less likely to know what organizational expectations exist, what outcomes to measure, or what theories in use are in operations" (Sinkula et al., 1997, p. 309). 
Learning orientation is essential for internationalized firms in two ways: first to identify opportunities in foreign markets and second for the growth and long-term success of internationalized firms (Dimitratos et al., 2012). According to (Autio et al., 2000) Born global firms are characterized by the feature of "learning advantage of newness". Extant literature has found that learning orientation is positively related to product innovation performance (Alegre \& Chiva, 2008; Baker $\&$ Sinkula, 1999; Calisir et al., 2013), newproduct success, capability development and long term firm performance (Alegre \& Chiva, 2008; Calantone et al., 2002; Calisir et al., 2013; Jantunen et al., 2008; Kropp et al., 2006; Real et al., 2014). But, unexpectedly, studies investigating the role of learning orientation in the international performance are significantly scarce in extant literature.

With the essential role of international learning orientation, a key aspect of organizational culture, this study, therefore, proposes the following hypothesis.

$\mathrm{H} 2$ : Learning Orientation (LO) is positively related to the international performance of born global firms

\section{Mediating effect of learning orientation}

Discussion on the indirect effect of learning orientation either as a moderator or a mediator on market orientation performance relationship has been acknowledged in previous scholarly works, but least understood area of research (Baker \& Sinkula, 1999; Keupp \& Gassmann, 2009; Knight \& Liesch, 2016; Mac \& Evangelista, 2016). Moreover, many studies are theoretically proposed research but not empirically tested. The indirect effect of learning orientation, together with market orientation, is more synergistic than its direct effect (Abbu \& Gopalakrishna, 2019; Ahmed et al., 2018; Baker \& Sinkula, 1999). According to Baker \& Sinkula (1999), learning orientation is a significant facilitator of firms' competitive advantage and the unique orientation that characterizes inimitability. Thus, the orientation through learning is inimitable and synergistic on accelerating firm performances than their direct effects.

Market orientation, as postulated in previous research works, largely depends on firms' learning orientation and is thus less effective if it fails to combine with learning orientation (Sinkula, et al., 1997). Strong market orientation brings useful learning opportunities for firms as it facilitates scanning the market environment and every stakeholder of a firm, representing different market forces, is a good source for learning (Ahmed, et al., 2018). Further to them, the process of knowledge acquisition on customers and competitors, knowledge dissemination and processing by means of market orientation is the key to learning orientation. Market orientation together with learning orientation encourage every employee in the firm to be alert, accumulate and disseminate market information and be responsible for necessary changes and improvements. Thus, market orientation is a source of learning orientation rather than its isolated impact on firm performance of born global firms (Ahmed et al., 2018; Baker \& Sinkula, 1999; Day, 1994). Though not inclusive, several studies have empirically examined the synergetic effect of market orientation and learning orientation on international performance and other outcome variables of firm growth, firm innovativeness, for example, (Ahmed et al., 2018; Day, 1994; Farrell, 2000; Kasim et al., 2018; Liu et al., 2002; Mac \& Evangelista, 2016).

Therefore, it is hypothesized that,

$\mathrm{H} 3$ : Learning orientation mediates the relationship between market orientation and the international performance of born global firms. 
Herath, H.M.T.S., KJM, 2021, 10 (02)

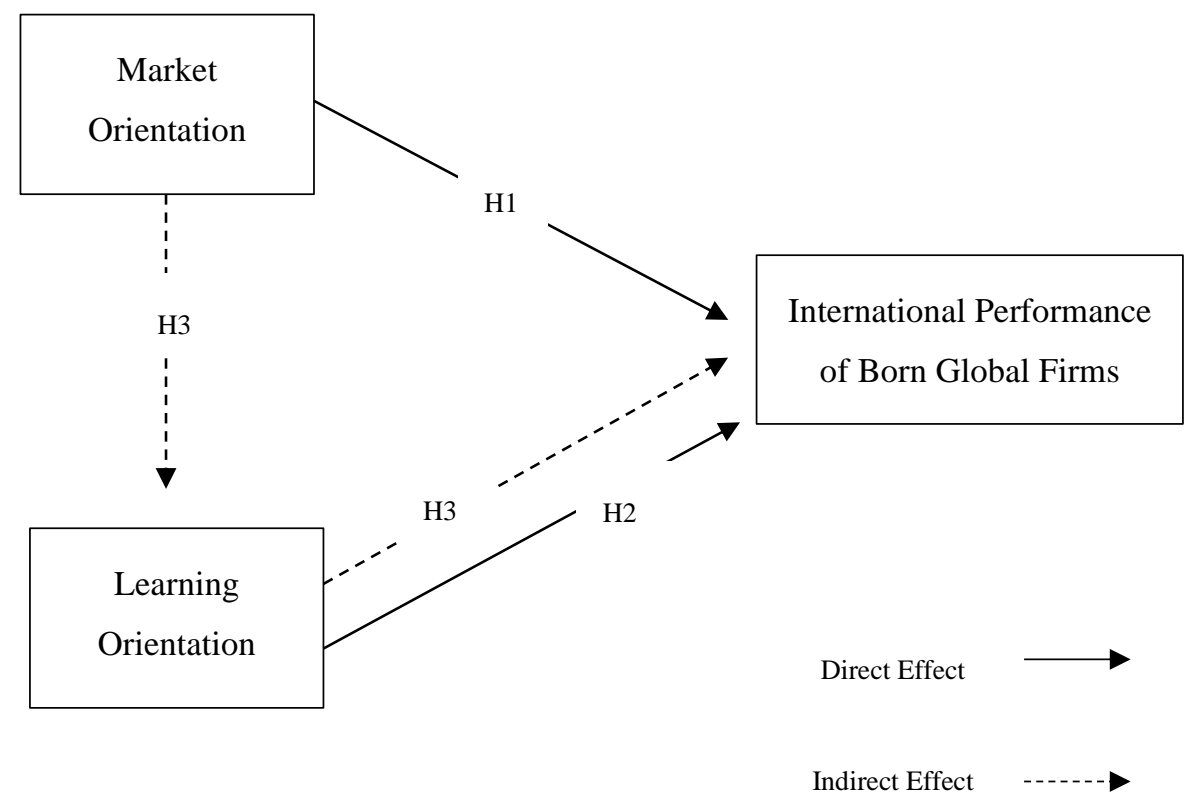

Figure 01: Conceptual Framework: MO-LO-Performance Relationship

\section{Research Design}

\section{Sampling and Data Collection}

Hypotheses testing was chosen as the research strategy that employed survey approach. The unit of analysis was firm-level and a structured questionnaire was utilized for primary data collection. The sample of the study comprises 225 ICT export entrepreneurial firms in Sri Lanka. Due to the unavailability of a single-up-to-date sample frame, the study used the database of Export Development Board of Sri Lanka (EDB), the only officially available database, as the target population. At the time of the survey conducted, 600 ICT export entrepreneurial firms had registered with the EDB, but only $80 \%$ of them were active in their businesses. Utilizing the total population sampling technique, out of all active 480 firms reached by the telephone, only 225 agreed to participate in the survey, representing $47 \%$ of the response rate. The respondents were informed of the importance of this research to academic and business community and were assured of confidentiality of their responses. The majority of the respondents was ownermanagers of the firm, but for a few cases, one of the senior managers of the firm participated in the survey. Initially, the survey questionnaire was emailed to all respondents before the interview with the purpose of saving time and easiness for both the respondents and the researcher. In collecting data for the questionnaire, a faceto-face interview could be held with more than $75 \%$ of respondents and for the rest, it was a telephone interview. This method was appropriate as the questionnaire was mailed earlier and quite simple and short. As an advantage of the interview method, no missing values were reported. A maximum of 15 to 20 minutes was taken to complete the questionnaire. In order to assess the response bias, the study compared the responses of the main variables from a sample $(n=25)$ of the earliest responding to those of a sample $(\mathrm{n}=$ 25) of the latest responding firms and no significant difference was reported in their mean values. Thus, response bias is not expected to affect the study results significantly. Table 1 shows the profile of the 
study sample summarized in terms of the main born global characteristics of time of internationalization, scale internationalization,

scope of internationalization, age of the firm and no of employees.

Table 01: Profile of the Sample

\begin{tabular}{llc}
\hline Firm Characteristic & & $\%$ \\
\hline Size (No. of Employees) & $<50$ employees & 76 \\
Age & During the period: 1990-2010 & 76 \\
Time taken to internationalization & Since inception & 68 \\
Scale of internationalization & Average export sales to total sales & 50 \\
Scope of internationalization & Maximum of 12 markets and on average & 4 markets
\end{tabular}

Source: Author's Work

\section{Measurements}

The scales used in the study were obtained from previous scholarly works. Market orientation was measured using seven items adapted from the original MKTOR scale developed by (Narver \& Slater, 1990). The seven-point Likert scale was used as originally proposed that ranges from 1 (Strongly Disagree) to 7 (Strongly Agree). The construct consists of three dimensions of customer orientation, competitor orientation and inter-functional coordination and four, three and three items were respectively used to measure each of these dimensions. In testing hypotheses, a higher-order construct of international market orientation was considered.

In measuring learning orientation, LO scale developed by (Sinkula et al., 1997) was utilized and 7 items were used. A seven-point Likert scale was used to measure the learning orientation anchored at 1 for strongly disagree and 7 for strongly agree. Learning orientation consists of three dimensions of commitment to learning measured using four items, shared vision and open-mindedness were measured by using three items each. Like market orientation, learning orientation was considered as a higher-order construct for data analysis purposes.
Though there are several different approaches to measure the international performance of born global firms, this study utilized the subjective approach that is the recent trend in entrepreneurship (Jantunen et al., 2008). Thus, this study measured the international performance of born global firms in terms of sales volume, market share, profitability and overall satisfaction, which was measured with a seven-point likert scale. The study used the original scale developed by (Knight \& Cavusgil, 2004) and measured it as a first-order construct.

\section{Data Analysis}

The study used both descriptive and inferential statistics for data analysis purposes. Descriptive analysis was mainly used to describe the socio-demographic characteristics of the sample of the study. In the descriptive analysis, frequencies, means, standard deviations skewness and kurtosis were used as univariate coefficients to measure the distribution, central tendency and dispersion of data included in the analysis. Correlation coefficients - the bivariate statistic - were produced to examine the relationships between two variables. Multivariate analysis was employed to analyze hypotheses and test the hypothesized dependency relationships of the conceptual model of the study (Hair Jr., et al., 2009). Structural equation modeling (SEM) 
was performed as the main statistical technique for this analysis purpose of the study. Multivariate analysis in SEM involves two steps: (1). assessing the measurement model through confirmatory factor analysis to assess how well-observed variables present the underlying latent constructs, (2). Assessing both the direct and indirect effects of dependency the relationships between market orientation, learning orientation and international performance of born global firms. The software packages of SPSS 20.0 and AMOS 23 version were utilized for data analysis purposes.

Prior to the multivariate analysis, the data set was tested for its goodness and to confirm the non-violation of multivariate assumptions. For this purpose, four main tests were carried out: (1). Testing for unidimensionality, (2). Testing for normality, (3). Testing for multicollinearity, and (4). Testing for homoscedasticity. In testing unidimensionality, Cronbach's alpha and confirmatory factor analysis were carried out. Normality was tested through both graphical and statistical analysis. Thus, the study used normal probability plots (Q-Q plots) and skewness and kurtosis statistics in this regard as recommended by (Hair 2010; Sekaran, 2016). Non- violation of multicollinearity assumption was tested through tolerance and the VIF value. And finally, scatterplot and boxplots were used to test non-violation of homoscedasticity. And the results confirm the non-violation of these assumptions.

\section{Analysis and Results}

\section{Descriptive Statistics}

Descriptive statistics provides a summary of the mean value, standard deviation and the correlation coefficient for all three constructs of market orientation, learning orientation and international performance. As table 2 reports, the mean value of all constructs is higher than 0.52 on a seven-point scale and while the international performance (5.98) reports the highest mean value, market orientation scores the lowest (5.79). For standard deviation, international performance reports the highest $(0.62)$ and learning orientation, the lowest (0.52). Further, all independent variables yield a low correlation between two variables and are significant at a $99 \%$ of the confidence level. Thus, the results show significantly low inter-correlation among the independent variables, and all are well below the critical value of 0.8

Table 02: Mean, Standard Deviation and Pearson Correlation of the Constructs

\begin{tabular}{llllll}
\hline & Mean & SD & MO & LO & IP \\
\hline Market Orientation & 5.79 & 0.58 & 1 & & \\
Learning Orientation & 5.84 & 0.52 & $0.423 * *$ & 1 & \\
International Performance & 5.98 & 0.62 & $0.782^{* *}$ & $0.759^{* *}$ & 1 \\
\hline
\end{tabular}

**Correlation is significant at the 0.01 level (2-tailed)

Source: Author's Work

\section{Confirmatory Factor Analysis}

At the first stage of the SEM, the confirmatory factor analysis (CFA) was conducted to confirm reliability and validity evidence in the study context - an emerging economy - that is completely different from the original study contexts and to assess the overall model fit of the measurement model.
The model achieved the adequate fit with the absolute fit indices: GFI $=0.903$, RMSEA $=$ 0.032; incremental indices: $\mathrm{CFI}=0.980$, NFI $=0.900$ and parsimony indices: PCFI $=$ $0.863, \mathrm{PNFI}=0.792$ and all indices are well above the respective accepted levels.

Reliability was assessed through standard factor loadings (FL) and composite reliability 
Herath, H.M.T.S., KJM, 2021, 10 (02)

(CR). As shown in Table 3, all standard internal consistency among the latent factor loadings of each construct are well above the recommended cut-off value of 0.7 as suggested by (Hair 2010). Further, since all $\mathrm{CR}$ values exceed 0.7 , it confirms the

constructs measured using different observed variables. Thus, the research instrument is of good reliability.

Table 03: Standard Factor Loadings, Average Variance Extracted and Composite Reliability of the Constructs of the Measurement Model

\begin{tabular}{llll}
\hline & MO & LO & IP \\
\hline Customer Orientation & 0.839 & & \\
\hline Competitor Orientation & 0.846 & & \\
\hline Inter-functional Coordination & 0.775 & & \\
\hline Commitment to Learning & & 0.737 & \\
\hline Shared Vision & & 0.856 & 0.773 \\
\hline Open Mindedness & & 0.825 & 0.793 \\
\hline Market Share & & & 0.807 \\
\hline Sales Growth & & & 0.765 \\
\hline Profitability & & $\mathbf{0 . 6 5 3}$ & $\mathbf{0 . 6 1 5}$ \\
\hline Overall Performance & $\mathbf{0 . 6 7 3}$ & $\mathbf{0 . 8 4 9}$ & $\mathbf{0 . 8 6 5}$ \\
\hline AVE & $\mathbf{0 . 8 6 1}$ & & \\
\hline CR & & &
\end{tabular}

Source: Author's Work

In assessing the construct validity of the reports the estimates of Farnell- Larcker research instrument, convergent validity and criterion. All square roots AVE estimates are discriminant validity were performed. The greater than the corresponding standardized average variance extracted (AVE) and CR correlation coefficients. All diagonal values were used to measure the convergent validity in bold represent the square root estimates of and as Hair (2010) recommends, AVE AVE. Thus, it confirms the discriminant exceeds the accepted cut-off value of 0.5 and validity of the constructs.

CR is above 0.7 as shown in table 3 . Table 4

Table 04: Farnell-Larceker Criterion Estimates for Discriminant Validity

\begin{tabular}{llll}
\hline & MO & LO & IP \\
\hline MO & $\mathbf{0 . 8 2 0}$ & & \\
LO & 0.421 & $\mathbf{0 . 8 0 8}$ & \\
IP & 0.783 & 0.758 & $\mathbf{0 . 7 8 4}$ \\
\hline
\end{tabular}

Source: Author's Work 


\section{Hypotheses Testing}

Since the initial full measurement model was accepted without modifications structural model was analyzed for hypotheses testing. The structural model, first, assessed the direct relationship between exogenous and endogenous variables (Mo - Performance relationship) to test $\mathrm{H} 1$ and $\mathrm{H} 2$ and subsequently, the mediating effect of learning orientation on MO - Performance relationship in testing $\mathrm{H} 3$. The model fit indices report no differences with the CFA.

The summary of the results of the path analysis is presented in table 5. Three hypotheses were established and all three hypotheses from $\mathrm{H} 1$ to $\mathrm{H} 3$ were supported as expected with significant $p$ values (***p $<0.01$ ). Thus, acceptance of $\mathrm{H} 1$ and $\mathrm{H} 2$ indicates that both market orientation and learning orientation positively and significantly influences the international performance of born global firms and confirms the positive direct effect. In testing the mediation effect of learning orientation, bootstrapping the indirect effect was performed. In supporting $\mathrm{H} 3$, it confirms both the direct effect () $.561, \mathrm{p}<0.000)$ and the indirect effect $(0.221, \mathrm{p}<0.000)$ of learning orientation on the MO-Performance relationship is significant. Since the direct effect of market orientation on international performance is significant, the indirect impact of learning orientation has a partial mediation effect on this relationship.

Table 05: The Summary of the Direct and Indirect Effect of MO and LO

\begin{tabular}{|c|c|c|c|c|c|c|c|}
\hline $\mathbf{H}$ & & $\begin{array}{l}\text { nesized } \\
\text { onship }\end{array}$ & & $\begin{array}{c}\text { Path } \\
\text { Coefficient }\end{array}$ & $\begin{array}{c}\mathbf{p} \\
\text { values }\end{array}$ & $\begin{array}{c}\text { Hypothesis } \\
\text { Results }\end{array}$ & $\begin{array}{c}\text { Mediation } \\
\text { Decision }\end{array}$ \\
\hline H1 & MO & IP & & 0.561 & $* * *$ & Supported & - \\
\hline $\mathrm{H} 2$ & LO & IP & & 0.522 & $* * *$ & Supported & - \\
\hline H3 & MO & LO & IP & 0.221 & $* * *$ & Supported & $\begin{array}{c}\text { Partial } \\
\text { Mediation }\end{array}$ \\
\hline
\end{tabular}

Source: Author's Work

\section{Discussion}

The results of this study provide a new standpoint in addressing a recent and intriguing question about the interrelationship between the two important organizational resources of market orientation, and learning orientation in an emerging context, Sri Lanka. Thus, the study attempted to investigate how the synergistic effect of market orientation and learning orientation together influence the international performance of born global firms. As the study found, both market orientation and learning orientation are significant drivers in predicting the international performance of born global firms. In supporting the findings of previous scholarly works that found significant positive relationship between market orientation, learning orientation and the international performance of born global firms, for example, (Abbu \& Gopalakrishna, 2019; Alegre \& Chiva, 2008; Baker \& Sinkula, 1999; Calantone et al., 2002; Calisir et al., 2013; Jantunen et al., 2008; Jaworski \& Kohli, 1993; Kropp et al., 2006, 2006; Mac \& Evangelista, 2016; Narver \& Slater, 1990; Real et al., 2014; Rodriguez Cano et al., 2004), this study re-confirms the said relationships in completely a new study context - an emerging economy of Sri Lanka. The findings of the study further, enrich the existing literature regarding the simultaneous effect and the relative importance of market and learning orientations on international performance as most of the previous scholarly works examined these two 
orientations either separately or only the direct effects. As per the findings on path coefficient values, market orientation $(\beta=$ $0.561)$ has a greater influence the international performance of born global firms than their learning orientation $(\beta=$ 0.522 ) and the study suggests that the influence of market orientation is higher than that of the influence of learning orientation. However, the magnitude of these dependency relationships may vary when the conceptual model is tested in a different study context other than the ICT export entrepreneurial firms in Sri Lanka.

Regarding the mediation effect of learning orientation on MO-Performance relationship, in consistent of previous findings of Ahmed et al., 2018; Day, 1994; Farrell, 2000; Kasim et al., 2018; Liu et al., 2002; Mac \& Evangelista, 2016), this study found that learning orientation mediates the relationship between market orientation and international performance of born global firms. Though the indirect effect is significant it is not synergistic as expected. Because the indirect effect of learning orientation on MO-Performance relationship reports just a partial mediation, and its magnitude effect $(\beta=0.221)$ is less than the direct effects. In conclusion, both market orientation and learning orientation are essential significant drivers of the international performance of born global firms. These firms see market and learning orientations as essential strategies to overcome their resource constraints and create sustainable competitive advantage in highly competitive and uncertain international market. Therefore, practicing a market-oriented learning culture within a firm always provides a competitive advantage for born global firms, ultimately leading to superior long-term performance. Market orientation is essential for a born global firm in two ways: first, to increase the profitability of the firm and second, for longterm success and survival of the firm (Slater \& Narver, 1995). The positive learning climate of a firm leads not only to enhance long-term firm performance but also other positive outcomes of product innovation and development, capability development, and new product success. According to Autio et al. (2000), born global firms are characterized by the feature of "learning advantage of newness". Thus, learning orientation is essential for internationalized firms in two ways: first to identify opportunities in foreign markets and the second for growth and the long-term success of internationalized firms. Also, international learning orientation facilitates to generate new resources and skills required for the superior international firm performance of those firms. Therefore, managers in born global firms should encourage employees to effectively utilize company time to pursue new knowledge even though it may not directly come under their immediate scope of work.

\section{Managerial Implications}

The findings of this study reveal the importance of market and learning orientations as essential organizational resources for resource-constraint born global firms to accelerate their superior international performance. Born global firms that operate extremely in a dynamic and complex business environment should, therefore, recognize the vital role of market and learning orientation as essential strategic orientations that facilitate them to seek their sustainable competitive advantage that ultimately enhances their superior international performance. Therefore, born global firms should capitalize on and develop market and learning capabilities to support further and refine their international strategies. As well, born global firms need to establish a market-oriented learning culture within their firms that facilitate them to strategically overcome resource constraints, identify international opportunities, enhance profitability, and for long-term success. Market orientation, and learning orientation are essential managerial skills and capabilities that must be supported by certain firm-level conditions which facilitate organizational learning. Get receive the 
maximum benefit of synergistic effect of market and learning orientations, born global firms, therefore, should come up with innovative ways and ideas to respond to changes and to establish possible market strategies through implicit learning, creative learning, learning by action and learning by trial and error. As well, implementing a proper mechanism for knowledge acquisition on customers and competitors, knowledge dissemination and processing by means of market orientation is essential for learning orientation. A combined effort of market orientation together with learning orientation encourages all employees in the firm to be alert, accumulate and disseminate market information and be responsible for necessary changes and improvements.

\section{Limitations and Future Research Directions}

The results of this study should be taken in light of some limitations that might influence the generalizability of the study findings. First, the sample was drawn from a particular industry - ICT export entrepreneurs in Sri Lanka, limiting to a particular segment may not truly represent all born global firms in Sri Lanka. However, to my best knowledge, available information on born global firms in the Sri Lankan context is yet unknown. As well, since the study population is unknown, a reliable sample couldn't be drawn. There is no single up-to-date official database regarding the ICT export entrepreneurs in Sri Lanka and hence, the study faced several difficulties in preparing complete information of sample frame. Therefore, the study used the only available database of EDB for this study purpose. This may impact generalizing the findings of this study.

Second, this study investigated in a developing country context, Sri Lanka which has greater economic, political and social instability. As such, these results may change when applied to other contexts where the business, economic, political and social environment is more stable. And also, same is true when findings are applied to several other industries other than ICT industry. There are many avenues of expanding this research model into several different study settings and sample settings for future research Third, this study examined the role of market and learning orientations in the international performance of born global firms, using cross-sectional data. It is worth to examining the role of market and learning orientation in predictors like international growth, firm innovation. This line of research also lacks more longitudinal studies that may appropriately explain the performance and growth of firms. 


\section{References}

Abbu, H. R., \& Gopalakrishna, P. (2019). Synergistic effects of market orientation implementation and internalization on firm performance: Direct marketing service provider industry. Journal of Business Research, S0148296319303558. https://doi.org/10.1016/j.jbusres.2019.06.004

Ahmed, F., Kitchlew, N., Bajwa, S., \& Shahzad, K. (2018). Congruence of market orientation and organizational learning: Performance perspective. Undefined. https://www.semanticscholar.org/paper/Congruence-of-market-orientation-andorganizational-Ahmed-Kitchlew/ae7f40f107311265de0f5f252b14b4773243a646

Akoorie, M. E. M., \& Sinha, P. (2012). International entrepreneurship: A critical analysis of studies in the past two decades and future directions for research [Review of International entrepreneurship: A critical analysis of studies in the past two decades and future directions for research, by I. K. Peiris]. Journal of International Entrepreneurship, 10(4), 279-324. https://doi.org/10.1007/s10843-012-0096-3

Alegre, J., \& Chiva, R. (2008). Assessing the impact of organizational learning capability on product innovation performance: An empirical test. Technovation, 28(6), 315-326. https://doi.org/10.1016/j.technovation.2007.09.003

Autio, E., Sapienza, H. J., \& Almeida, J. G. (2000). EFFECTS OF AGE AT ENTRY, KNOWLEDGE INTENSITY, AND IMITABILITY ON INTERNATIONAL GROWTH. Academy of Management Journal, 17.

Baker, W. E., \& Sinkula, J. M. (1999). The synergistic effect of market orientation and learning orientation on organizational performance. Journal of the Academy of Marketing Science, 27(4), 411. https://doi.org/10.1177/0092070399274002

Barney, J. (1991). Firm Resources and Sustained Competitive Advantage. Journal of Management, 17(1), 99-120. https://doi.org/10.1177/014920639101700108

Calantone, R. J., Cavusgil, S. T., \& Zhao, Y. (2002). Learning orientation, firm innovation capability, and firm performance. Industrial Marketing Management, 31(6), 515-524. https://doi.org/10.1016/S0019-8501(01)00203-6

Calisir, F., Altin Gumussoy, C., \& Guzelsoy, E. (2013). Impacts of learning orientation on product innovation performance. The Learning Organization, 20(3), 176-194. https://doi.org/10.1108/09696471311328442

Cavusgil, S. T., \& Knight, G. (2015). The born global firm: An entrepreneurial and capabilities perspective on early and rapid internationalization. Journal of International Business Studies, 46(1), 3-16. https://doi.org/10.1057/jibs.2014.62

Charles, L., Joel, C., \& Samwel, K. C. (2012). Market orientation and firm performance in the manufacturing sector in Kenya. http://ir.mu.ac.ke:8080/jspui/handle/123456789/2631

Chun, L. Y., Tian, L., \& Jing, Y. (2014). The Effect of Born International's International Strategies on its Subsequent Development: Taking the Accumulated Overseas Market Resources as the Moderating Effects. The Anthropologist, 17(3), 687-700. https://doi.org/10.1080/09720073.2014.11891483 
Covin, J. G., \& Miller, D. (2014). International Entrepreneurial Orientation: Conceptual Considerations, Research Themes, Measurement Issues, and Future Research Directions. Entrepreneurship Theory and Practice, 38(1), 11-44. https://doi.org/10.1111/etap.12027

Covin, J. G., \& Slevin, D. P. (1991). A Conceptual Model of Entrepreneurship as Firm Behavior. Entrepreneurship Theory and Practice, 16(1), 7-26. https://doi.org/10.1177/104225879101600102

Day, G. S. (1994). The Capabilities of Market-Driven Organizations. Journal of Marketing, 58(4), 37-52. https://doi.org/10.2307/1251915

Deng, S., \& Dart, J. (1994). Measuring market orientation: A multi-factor, multi-item approach. Journal of Marketing Management, 10(8), 725-742. https://doi.org/10.1080/0267257X.1994.9964318

Dimitratos, P., \& Plakoyiannaki, E. (2003). Theoretical Foundations of an International Entrepreneurial Culture. Journal of International Entrepreneurship, 1(2), 187-215. https://doi.org/10.1023/A:1023804318244

Dimitratos, P., Voudouris, I., Plakoyiannaki, E., \& Nakos, G. (2012). International entrepreneurial culture-Toward a comprehensive opportunity-based operationalization of international entrepreneurship. International Business Review, 21(4), 708-721. https://doi.org/10.1016/j.ibusrev.2011.08.001

Export development Board of Sri Lanka. (2011). ICT Export Value Survey 2010 Final Report - Slasscom. https://slasscom.lk/ict-export-value-survey-2010-final-report/

Falahat, M., Knight, G., \& Alon, I. (2018). Orientations and capabilities of born global firms from emerging markets. International Marketing Review, 35(6), 936-957. https://doi.org/10.1108/IMR-01-2017-0021

Farrell, M. A. (2000). Developing a Market-Oriented Learning Organisation. https://doi.org/10.1177/031289620002500205

Felzensztein, C., Ciravegna, L., Robson, P., \& Amorós, J. E. (2015). Networks, Entrepreneurial Orientation, and Internationalization Scope: Evidence from Chilean Small and Medium Enterprises. Journal of Small Business Management, 53, 145-160. https://doi.org/10.1111/jsbm.12188

Gabrielsson, M., Gabrielsson, P., \& Dimitratos, P. (2014). International Entrepreneurial Culture and Growth of International New Ventures. Management International Review, 54(4), 445-471. https://doi.org/10.1007/s11575-014-0213-8

Hair, J. F. (Ed.). (2010). Multivariate data analysis: A global perspective (7. ed., global ed). Pearson.

Hartsfield, S., Johansen, D., \& Knight, G. (2008). Entrepreneurial Orientation, Strategy, and Marketing Capabilities. International Business, 27.

Herath, H. M. T. S., \& Karunaratne, H. D. (2015). Issues and Challenges of Born Global Entrepreneurs: Information \&amp; Communication Technology (ICT) Exporters in Sri Lanka. 5th Annual International Conference on Business Strategy and Asian Economic Transformation

(BizStrategy 2015). 
https://www.academia.edu/24796127/Issues_and_Challenges_of_Born_Global_Entrepreneu rs_Information_and_Communication_Technology_ICT_Exporters_in_Sri_Lanka

Jantunen, A., Nummela, N., Puumalainen, K., \& Saarenketo, S. (2008). Strategic orientations of born globals-Do they really matter? Journal of World Business, 43(2), 158-170. https://doi.org/10.1016/j.jwb.2007.11.015

Jaworski, B. J., \& Kohli, A. K. (1993). Market Orientation: Antecedents and Consequences. Journal of Marketing, 57(3), 53. https://doi.org/10.2307/1251854

Kasim, A., Ekinci, Y., Altinay, L., \& Hussain, K. (2018). Impact of market orientation, organizational learning and market conditions on small and medium-size hospitality enterprises. Journal of Hospitality Marketing \& Management, 27(7), 855-875. https://doi.org/10.1080/19368623.2018.1438955

Keupp, M. M., \& Gassmann, O. (2009). The Past and the Future of International Entrepreneurship: A Review and Suggestions for Developing the Field. Journal of Management, 35(3), 600-633. https://doi.org/10.1177/0149206308330558

Knight, G. A. (2001). Journal of International Management, 7(3), 155-171. https://doi.org/10.1016/S1075-4253(01)00042-4

Knight, G. A., \& Cavusgil, S. T. (2004). Innovation, organizational capabilities, and the bornglobal firm. Journal of International Business Studies, 35(2), 124-141. https://doi.org/10.1057/palgrave.jibs.8400071

Knight, G. A., \& Liesch, P. W. (2016). Internationalization: From incremental to born global. Journal of World Business, 51(1), 93-102. https://doi.org/10.1016/j.jwb.2015.08.011

Kohli, A. K., \& Jaworski, B. J. (1990). Market Orientation: The Construct, Research Propositions, and Managerial Implications. Journal of Marketing, 54(2), 1. https://doi.org/10.2307/1251866

Kropp, F., Lindsay, N. J., \& Shoham, A. (2006). Entrepreneurial, market, and learning orientations and international entrepreneurial business venture performance in South African firms. International Marketing Review, 23(5), 504-523. https://doi.org/10.1108/02651330610703427

Liu, S. S., Luo, X., \& Shi, Y.-Z. (2002). Integrating Customer Orientation, Corporate Entrepreneurship, and Learning Orientation in Organizations-in-Transition: An Empirical Study. https://doi.org/10.1016/S0167-8116(02)00098-8

Long, H. C. (2013). The Relationship Among Learning Orientation, Market Orientation, Entrepreneurial Orientation, and Firm Performance of Vietnam Marketing Communications Firms. Philippine Management Review, 20(0), Article 0. https://journals.upd.edu.ph/index.php/pmr/article/view/3643

Lumpkin, G. T., \& Dess, G. G. (1996). Clarifying the Entrepreneurial Orientation Construct and Linking It to Performance. The Academy of Management Review, 21(1), 135. https://doi.org/10.2307/258632

Mac, L., \& Evangelista, F. (2016). The Relative Impact of Market Orientation and Entrepreneurship on Export Performance: Do We Really Know Enough? Journal of Global Marketing, 29(5), 266-281. https://doi.org/10.1080/08911762.2016.1196285 
Masa'deh, R., Al-Henzab, J., Tarhini, A., \& Obeidat, B. Y. (2018). The associations among market orientation, technology orientation, entrepreneurial orientation and organizational performance. Benchmarking: An International Journal, 25(8), 3117-3142. https://doi.org/10.1108/BIJ-02-2017-0024

Moen, Ø., \& Servais, P. (2002). Born Global or Gradual Global? Examining the Export Behavior of Small and Medium-Sized Enterprises. Journal of International Marketing, 10(3), 49-72. https://doi.org/10.1509/jimk.10.3.49.19540

Narver, J. C., \& Slater, S. F. (1990). The Effect of a Market Orientation on Business Profitability. Journal of Marketing, 54(4), 20. https://doi.org/10.2307/1251757

Nummela, N., Puumalainen, K., \& Saarenketo, S. (2005). International Growth Orientation of Knowledge-Intensive SMES. Journal of International Entrepreneurship, 3(1), 5-18. https://doi.org/10.1007/s10843-005-0350-z

Oviatt, B. M., \& McDougall, P. P. (2005). Defining International Entrepreneurship and Modeling the Speed of Internationalization. Entrepreneurship Theory and Practice, 29(5), 537-554. https://doi.org/10.1111/j.1540-6520.2005.00097.x

Peiris, I. K., Akoorie, M. E. M., \& Sinha, P. (2012). International entrepreneurship: A critical analysis of studies in the past two decades and future directions for research. Journal of International Entrepreneurship, 10(4), 279-324. https://doi.org/10.1007/s10843-012-0096-3

Rauch, A., Wiklund, J., Lumpkin, G. T., \& Frese, M. (2009). Entrepreneurship Theory and Practice, 33(3), 761-787. https://doi.org/10.1111/j.1540-6520.2009.00308.x

Real, J. C., Roldán, J. L., \& Leal, A. (2014). From Entrepreneurial Orientation and Learning Orientation to Business Performance: Analysing the Mediating Role of Organizational Learning and the Moderating Effects of Organizational Size. British Journal of Management, 25(2), 186-208. https://doi.org/10.1111/j.1467-8551.2012.00848.x

Rialp, A., \& Rialp, J. (2007). Faster and More Successful Exporters: An Exploratory Study of Born Global Firms from the Resource-Based View. Journal of Euromarketing, 16(1-2), 7186. https://doi.org/10.1300/J037v16n01_06

Rialp, A., Rialp, J., \& Knight, G. A. (2005). The phenomenon of early internationalizing firms: What do we know after a decade (1993-2003) of scientific inquiry? International Business Review, 14(2), 147-166. https://doi.org/10.1016/j.ibusrev.2004.04.006

Rodriguez Cano, C., Carrillat, F. A., \& Jaramillo, F. (2004). A meta-analysis of the relationship between market orientation and business performance: Evidence from five continents. International Journal of Research in Marketing, 21(2), 179-200. https://doi.org/10.1016/j.ijresmar.2003.07.001

Sekaran. (2016). Research Methods For Business: A Skill Building Approach, 7th Edition | Wiley. Wiley.Com. https://www.wiley.com/enus/Research+Methods+For+Business $\% 3 \mathrm{~A}+\mathrm{A}+$ Skill+Building+Approach $\% 2 \mathrm{C}+7$ th+Editionp-9781119266846

Sinkula, J. M., Baker, W. E., \& Noordewier, T. (1997). A Framework for Market-Based Organizational Learning: Linking Values, Knowledge, and Behavior. Journal of the Academy of Marketing Science, 25(4), 305-318. https://doi.org/10.1177/0092070397254003 
Slater, S. F., \& Narver, J. C. (1995). Market Orientation and the Learning Organization. Journal of Marketing, 59(3), 63. https://doi.org/10.2307/1252120

Sundqvist, S., \& Kuivalainen, O. (2009). Relationships between the dimensions of international growth orientation, environmental turbulence, and strategic orientations. In R. R. Sinkovics \& P. N. Ghauri (Eds.), Advances in International Marketing (Vol. 20, pp. 89 123). Emerald Group Publishing Limited. https://doi.org/10.1108/S14747979(2009)0000020007

Wang, C. L. (2008). Entrepreneurial Orientation, Learning Orientation, and Firm Performance. Entrepreneurship Theory and Practice, 32(4), 635-657. https://doi.org/10.1111/j.1540-6520.2008.00246.x

Wang, F., Wei, J., \& Shi, X. (2018). Compliance with recommended protective actions during an H7N9 emergency: A risk perception perspective. Disasters, 42(2), 207-232. https://doi.org/10.1111/disa.12240

Wernerfelt, B. (1984). A resource-based view of the firm. Strategic Management Journal, 5(2), 171-180. https://doi.org/10.1002/smj.4250050207

Wiklund, J., \& Shepherd, D. (2005). Entrepreneurial orientation and small business performance: A configurational approach. Journal of Business Venturing, 20(1), 71-91. https://doi.org/10.1016/j.jbusvent.2004.01.001 